\title{
To the Immune Status of the Indigenous and Foreign Population of the Republic of Sakha (Yakutia)
}

\author{
Victoria Egorova $a^{1, *}$, Nikolay Gogolev ${ }^{2}$ and Eya Egorova ${ }^{2}$ \\ ${ }^{1}$ M.K. Ammosov North-Eastern Federal University Clinic, Russia \\ ${ }^{2}$ Medical Institute, M.K. Ammosov North-Eastern Federal University, Russia \\ ${ }^{*}$ Corresponding author. Email: ve.egorova@s-vfu.ru
}

\begin{abstract}
In the north, the human body is influenced by a whole complex of climatic, geographic, geophysical, environmental factors of the external environment. These factors have an adverse effect on human health. The health state of the population reflects the living conditions, the state of immune protection and the degree of adaptation to adverse conditions. This article is devoted to the study of the immunological status of the population of the Republic of Sakha (Yakutia). The study was carried out using the immunoenzyme method of blood analysis: immunoglobulins of A, M, G, E and A serum, IL-18, IL-10. The indicators of the immune status of both the indigenous population and the newcomers of 4 uluses (Verkhnevilyuisky, Tattinsky, Verkhoyansky, Eveno-Bytantaysky) and the city of Yakutsk RS (Ya) are given. The study results of the immune system state for the population of ecologically unfavorable regions of the Far North indicate that technogenic pollution of the environment forms immunodeficiency conditions with a risk of allergic pathology. Our immune-epidemiological studies have confirmed that chronic diseases are clinical masks of immunodeficiency conditions associated with the immune phenotype of the Northern population.
\end{abstract}

Keywords: immune status, indigenous population, foreign population, Republic of Sakha, Yakutia

\section{INTRODUCTION}

The Republic of Sakha (Yakutia) is the largest constituent entity of the Russian Federation, located in the northeastern part of the Eurasian continent. It is part of the Far Eastern Federal District. The entire territory of the republic belongs to the regions of the Far North. The climate is sharply continental, subarctic. At present, the development of natural resources and the development of industry in the region, without taking into account the specific conditions of the region, have become the reasons for the emergence of areas of environmental tension in the places of mining and the deterioration of the ecological situation in the region as a whole.

In the north, the human body is influenced by a whole complex of climatic, geographic, geophysical, and environmental factors of the external environment. These factors have an adverse effect on human health, deplete the body's adaptive reserves, lead to the appearance of diseases, change their course, contribute to premature aging and life reduction.

However, the population of the republic is less than one million people (964 330), which makes the population density in it one of the lowest in Russia (only the Chukotka and Nenets Autonomous Districts have a lower density). In terms of ethnic composition, the indigenous population is represented by $49.9 \%$ Yakuts, $2.2 \%$ Evenks, $1.6 \%$ Evens, the remaining $46.3 \%$ newcomer population.

The formation of the newcomer population in the North occurs in extreme climatic and socio-economic conditions of the environment and is based on the individual characteristics of an individual. External environmental factors of the Far North affect almost all body systems. The process of adaptation to the extreme conditions of the Far North is uneven and depends on the period of a person's stay in the Far North (northern experience) but the first three years are the most difficult. If a person has adapted to the conditions of the 
Far North for three years, then in the next seven years, provided the right lifestyle, work schedule, rest, nutrition, travel and proper medical care, his body handles extreme loads caused by space and natural factors. In most cases, after the expiration of this period, a period of exhaustion of the body begins since the latter has no longer sufficient reserve capabilities to function normally under these conditions. The duration of the normal period can be much less and much more than ten years. It depends on a person, constitution, lifestyle, mode of work and rest, etc.

Cold is one of the main environmental factors of the North, the human body has to adapt to it. The interaction of the newcomers' organism with a complex of factors of the North is accompanied by a complex restructuring of regulatory, physiological, and metabolic processes and the development of a state of peculiar tension. Under the influence of a long-acting intense cold stimulus $\left(-15-40{ }^{\circ} \mathrm{C}\right)$, an unbalanced combination of heat production and heat transfer is characteristic, physical thermoregulation is restructured in the direction of accelerating the restoration of blood flow in the cooled areas of the body, which leads to an increase in the heat-protective properties of the body.

The health state of the population reflects the living conditions, the state of immune protection and the degree of adaptation to adverse conditions. Modern conditions in the North are uncomfortable for humans. The combined influence of climatic and environmental factors sharply aggravates their adverse effect on the human body, causes the development of severe stress reactions [8].

The results of clinical studies have shown a high incidence of chronic forms of pathology among the indigenous population. In all studied regions, chronic diseases of the digestive system, blood circulation, respiratory system, urinary tract and musculoskeletal system are widespread. The widespread prevalence of chronic inflammatory diseases of the ENT organs (chronic tonsillitis, chronic otitis media, rhinitis), viral and bacterial infections of the genitourinary system and the respiratory tract indicate low immunological resistance of the indigenous population, the presence of clinical signs of immunological deficiency (IU) [1].

Numerous studies have established that in the first year of a person's residence in the North, the human body is in a critical state, when there is a radical restructuring of the work of various body systems. It has been proven that the process of human adaptation in the Far North is accompanied by the formation of a symptom complex similar to chronic hypoxia with corresponding changes in the respiratory, circulatory and blood systems, aimed at "fighting" for oxygen.

The state of human health is largely determined by the level of immune reactivity. The level of immunological reactivity is an indicator of the state of life support systems. Various types of immune status under stress, the effect of environmental and social factors, are described. However, cellular-humoral fluctuations observed during adaptation disorders and in an uncomfortable living environment cannot be regarded solely as manifestations of the influence of the external environment on the body. It is known that the level of human immunological reactivity is a genetically determined factor and depends on a number of constitutional parameters.

This allows the use of immunological method for diagnosing premorbid conditions and predicting the consequences of environmental factors $[9,10]$

However, unfortunately, there is still little information about immunological monitoring of the health state of the population for the studied territories.

The purpose of the study: to study the indicators of the immunological status of the Republic of Sakha (Yakutia) population using the immunoenzyme method

\section{MATERIALS AND METHODS}

The object of the study is the population of 4 uluses (Verkhnevilyuisky, Tattinsky, Verkhoyansky, EvenoBytantaysky) and the city of Yakutsk of Republic of Sakha (Yakutia) (Table 1). Within the framework of this study, the population sample included the indigenous population (Sakha, Evenki, Evens, Dolgans, Yukaghirs, Chukchi) and representatives of the newcomer population (Russians, Ukrainians, etc.). We identified these population groups as indigenous and newcomers.

Table 1. Distribution of the surveyed by age and gender

\begin{tabular}{|c|c|c|c|}
\hline Age & Male & Female & Both genders \\
\hline \multicolumn{4}{|c|}{ Indigenous population } \\
\hline 18-59 years old & 424 & 1108 & 1532 \\
\hline 60 and older & 123 & 324 & 447 \\
\hline Total & 547 & 1432 & 1979 \\
\hline \multicolumn{4}{|c|}{ Newcomer population } \\
\hline $18-59$ years old & 360 & 597 & 957 \\
\hline 60 and older & 22 & 118 & 140 \\
\hline Total & 382 & 715 & 1097 \\
\hline \multicolumn{4}{|c|}{ Indigenous and newcomer population } \\
\hline Total & 929 & 2147 & 3076 \\
\hline
\end{tabular}

To accomplish the tasks set in this research work, an analysis of medical and demographic indicators and a comprehensive medical examination of the population in 4 uluses (Verkhnevilyuisky, Tattinsky, Verkhoyansky, Eveno-Bytantaysky) and the city of Yakutsk of Republic of Sakha (Yakutia) were carried 
out. Participation in the study was completely voluntary. The clinically useful information obtained was available to study participants.

The program of the study of immunological parameters included: venous blood sampling into vacutainers with coagulation activators (to obtain serum) in the morning on an empty stomach, 10-12 hours after eating. The enzyme immunoassay of blood was carried out from the material obtained in the laboratory of the Clinic of the Medical Institute of the North-Eastern Federal University named after M.K. Ammosova including immunoglobulins A, M, G, $\mathrm{E}$ and A serum, IL-18, IL-10. The obtained results were subjected to statistical processing.

\section{RESULTS}

Laboratory signs of destabilization of immune homeostasis are high heterogeneity and imbalance of serum immunoglobulins $\mathrm{A}, \mathrm{M}$ and $\mathrm{G}$ [7].

The results of immunological studies for the indigenous population of Yakutia are presented in Table 2. The average content of serum immunoglobulins of classes A, M, G and E correspond to the reference values of the laboratory and generally accepted norms, regardless of gender.

Table 2. Immune status of indigenous people

\begin{tabular}{|c|c|c|c|c|c|c|c|c|c|c|}
\hline \multirow{2}{*}{$\begin{array}{l}\text { Laboratory } \\
\text { reference values }\end{array}$} & \multicolumn{3}{|c|}{ Both genders } & \multicolumn{3}{|l|}{ Male } & \multicolumn{3}{|c|}{ Female } & \multirow[t]{2}{*}{ p } \\
\hline & Me & $10 \%$ & $90 \%$ & Me & $10 \%$ & $90 \%$ & Me & $10 \%$ & $90 \%$ & \\
\hline \multicolumn{11}{|l|}{$\lg A$} \\
\hline $0.7-3.0 \mathrm{~g} / \mathrm{I}$ & 2.63 & 1.73 & 3.86 & 2.51 & 1.68 & 3.6 & 2.64 & 1.74 & 3.9 & 0.1822 \\
\hline \multicolumn{11}{|l|}{$\lg G$} \\
\hline $7.0-16.0 \mathrm{~g} / \mathrm{I}$ & 12.91 & 9.79 & 16.42 & 12.18 & 8.9 & 15.27 & 13.27 & 10.16 & 16.73 & 0.001 \\
\hline \multicolumn{11}{|l|}{$\lg M$} \\
\hline $0.4-2.3 \mathrm{~g} / \mathrm{I}$ & 1.04 & 0.55 & 5.04 & 0.9 & 0.42 & 1.81 & 1.09 & 0.58 & 2.07 & 0.001 \\
\hline \multicolumn{11}{|l|}{$\lg E$} \\
\hline 0-100 ME & 65.95 & 8.83 & 447.9 & 92.05 & 13.64 & 494.5 & 59.9 & 8.03 & 417.7 & 0.002 \\
\hline \multicolumn{11}{|l|}{ IL-10 } \\
\hline 0-9.1 pg / ml & 10 & 7.54 & 14 & 10 & 7.4 & 14.2 & 10 & 8.49 & 12.9 & 0.477 \\
\hline \multicolumn{11}{|l|}{$\mathrm{IL}-18$} \\
\hline 0-261 pg / ml & 138.5 & 50.1 & 200.2 & 134.5 & 51.6 & 199.3 & 140 & 34.9 & 204 & 0.96 \\
\hline
\end{tabular}

As it is commonly known, there are 2 types of $\operatorname{IgA}$ : serum and secretory. The most part of $\operatorname{IgA}$ is present not in the serum, but on the surface of the mucous membranes. Antibodies of class A ( $\operatorname{IgA}$ ) begin to form and are available for detection from the second day after the onset of the disease, peak after 2 weeks and persist for a long time. High levels of $\operatorname{IgA}$ antibodies require close medical supervision. The disease may occur in a severe form [1].

The immunoglobulin $\mathrm{A}(\operatorname{Ig} \mathrm{A})$ test is prescribed to assess the severity of diseases in which local immunity is involved. The results of $\operatorname{IgA}$ examination allow to determine the form and stage of the disease course, as well as to develop the most effective treatment tactics [2].

Its main role is to protect the respiratory, genitourinary, and gastrointestinal tract from infection. An increase in the IgA content in the blood occurs in chronic infections, especially of the gastrointestinal tract and respiratory tract [8].
When analyzing deviations of immunological parameters from the norm, it was found that in the indigenous population, the $\operatorname{IgA}$ content was increased among $35.2 \%$ of the surveyed (Table 3 ).

Table 3. Frequency of deviations of immunological parameters from the norm in $\%$

\begin{tabular}{|l|l|l|l|}
\hline Indicator & Below norm & Norm & Above norm \\
\hline $\mathrm{IgA} \mathrm{g} / \mathrm{l}$ & 0 & 64.8 & 35.2 \\
\hline $\mathrm{IgG} \mathrm{g} / \mathrm{l}$ & 0.5 & 85.9 & 13.5 \\
\hline $\mathrm{IgM} \mathrm{g} / \mathrm{l}$ & 3.7 & 89.2 & 7.0 \\
\hline $\mathrm{IgE} \mathrm{ME}$ & 0 & 62.1 & 37.9 \\
\hline $\mathrm{IL}-10 \mathrm{pg} / \mathrm{ml}$ & - & 37.9 & 62.1 \\
\hline $\mathrm{IL}-18 \mathrm{pg} / \mathrm{ml}$ & - & 100 & - \\
\hline
\end{tabular}

IgM in blood serum agglutinate bacteria, neutralize viruses, activate complement, are the first to react to antigens that have entered the body and trigger further immune defense. They play an important role in the elimination of the pathogen from the bloodstream, in the 
activation of phagocytosis. A significant increase in the concentration of $\operatorname{IgM}$ in the blood is observed in a number of infections and indicates an acute inflammatory process. The analysis of the obtained data revealed that the IgM content in the blood was increased among $7 \%$ and decreased among $3.7 \%$ of the surveyed indigenous population.

IgG class antibodies play a fundamental role in providing long-term humoral immunity for infectious diseases and account for about $75-80 \%$ of all serum immunoglobulins and $10-20 \%$ of total serum protein. IgG deficiency leads to a weakening of the body's resistance to infections. IgG synthesis and its serum level increase in response to a chronic infection or autoimmune disease (many clinically important autoantibodies belong to the IgG class) [2].

Immunoglobulins $\mathrm{E}$ are produced locally, mainly in the submucosal layer of tissues in contact with the external environment: in the skin, respiratory tract, gastrointestinal tract, tonsils, adenoids. The IgE content in the blood is negligible. IgE is responsible for the development of allergic reactions. Increased levels of total IgE are associated with immediate-type hypersensitivity. People suffering from allergy have increased level of IgE both during and between atopic attacks. The IgE concentration depends on the duration of the disease and the number of previous contacts with the allergen [3-6]. The study of the immunological parameters of the indigenous population revealed high parameters of the IgE content among $37.9 \%$ of the surveyed.

Studies of immunological reactivity are an important source of information on the state of the body's adaptive reserves [2]. The results of the study of the immune status showed that the newcomer population has a tendency to activate the immune system associated with adaptive mechanisms (Tables 4 and 5).

Table 4. Immune status of the newcomer population.

\begin{tabular}{|c|c|c|c|c|c|c|c|c|c|c|}
\hline \multirow{2}{*}{$\begin{array}{l}\text { Laboratory } \\
\text { reference values }\end{array}$} & \multicolumn{3}{|c|}{ Both genders } & \multicolumn{3}{|l|}{ Male } & \multicolumn{3}{|c|}{ Female } & \multirow[t]{2}{*}{$p$} \\
\hline & $\mathrm{Me}$ & $10 \%$ & $90 \%$ & $\mathrm{Me}$ & $10 \%$ & $90 \%$ & $\mathrm{Me}$ & $10 \%$ & $90 \%$ & \\
\hline $\begin{array}{l}\lg A \\
0.7-3.0 \mathrm{~g} / 1\end{array}$ & 3.2 & 2.9 & 3.6 & 3.2 & 2.9 & 3.7 & 3.2 & 2.9 & 3.6 & 0.832 \\
\hline $\begin{array}{l}\lg G \\
7.0-16.0 \mathrm{~g} / \mathrm{I}\end{array}$ & 6.3 & 4.0 & 7.3 & 6.3 & 4.5 & 7.3 & 6.1 & 3.5 & 7.4 & 0.301 \\
\hline $\begin{array}{l}\lg M \\
0.4-2.3 \mathrm{~g} / 1\end{array}$ & 3.6 & 3.3 & 3.8 & 3.7 & 3.3 & 3.8 & 3.6 & 3.3 & 3.8 & 0.532 \\
\hline $\begin{array}{l}\text { IgE } \\
0-100 \mathrm{ME}\end{array}$ & 70.40 & 9.73 & 491.55 & 67.70 & 9.76 & 497.7 & 73.1 & 6.60 & 491.9 & 0.759 \\
\hline $\begin{array}{l}\text { IL } 10 \\
0-9.0 \mathrm{pg} / \mathrm{ml}\end{array}$ & 0.00 & 0.00 & 1.20 & 0.00 & 0.00 & 0.60 & 0.00 & 0.00 & 1.89 & 0.578 \\
\hline $\begin{array}{l}\text { IL } 18 \\
0-260 \mathrm{pg} / \mathrm{ml}\end{array}$ & 45.6 & 2.72 & 174.15 & 46.64 & 3.07 & 172.9 & 44.4 & 0.07 & 193.2 & 0.792 \\
\hline
\end{tabular}

Table 5. Frequency of deviations of immunological indicators from the norm in $\%$ among the newcomer population

\begin{tabular}{|l|l|l|l|}
\hline Indicator & Below norm & Norm & \\
\hline $\mathrm{lgA} \mathrm{g} \mathrm{/} \mathrm{I}$ & 1.3 & 20.1 & 78.5 \\
\hline $\mathrm{lgG} \mathrm{g} / \mathrm{I}$ & 77.2 & 22.8 & - \\
\hline $\mathrm{IgM} \mathrm{g} \mathrm{/} \mathrm{I}$ & 2.0 & 2.0 & 96.0 \\
\hline $\mathrm{IgE} \mathrm{ME}$ & - & 62.1 & 37.9 \\
\hline $\mathrm{IL} 10 \mathrm{pg} / \mathrm{ml}$ & - & 100 & - \\
\hline $\mathrm{IL} 18 \mathrm{pg} / \mathrm{ml}$ & - & 98 & 2 \\
\hline
\end{tabular}

According to the results of our studies, the peculiarities of adaptation of newcomers in the winter season are characterized by the following differences in the indicators of the immune status of newcomers of Yakutia: high parameters of IgE ME were observed among $37.9 \%$, the content of $\operatorname{IgA}$ g/l and IgM g/l above the standard indicators were recorded among the majority of the surveyed (78.5 and $96.0 \%)$, with the standard indicators of IL-10 and IL-18.

According to the results of the studies, the population of Yakutia is characterized by a tendency to an increased content of $\operatorname{IgA}$, which indicates the prevalence of inflammatory processes in the mucous membranes of the respiratory, digestive, and urinary system. Increased levels of total IgE are associated with population allergy to various allergens. In addition, the 
results of the study of the immune status showed that the newcomer population has a tendency to activate the immune system associated with adaptive mechanisms. A significant increase in the concentration of $\operatorname{IgM}$ $(96.0 \%)$ in the blood of the newcomer population indicates an acute inflammatory process.

Our immune-epidemiological studies have confirmed that chronic diseases are clinical masks of immunodeficiency conditions associated with the immune phenotype of the Northern population.

Thus, the results of studies of the state of the immune system for the population of ecologically unfavorable regions of the Far North indicate that technogenic pollution of the environment forms immunodeficiency states with the risk of developing allergic pathology. Promising methodological approaches to risk management are the scientific substantiation of the valeological and ecological rehabilitation of the population and the development of screening technology, readily available methods for predicting ecological-associated immunopathological diseases.

\section{REFERENCES}

[1] O.N Ivanova, E.F. Argunov, S.N. Alekseev et al., Wiadomocsi Lekarskis LXVII(4) (2015) 534-536.

[2] N. Amino, O. Tanizawa, K. Miyai et al., Obstet. Gynecol. 52 (1978) 415-420.

[3] H.G. Durkin, H. Bazin, B.H. Waksman, Exp. Med. 154 (1981) 640-648.

[4] T. Shirakawa, K. Morimoto, S. Sasaki et al., J. Epidemiol. 13 (1997) 395-402.

[5] P. Koraka, B. Murgue, X. Deparis et al., J. Med. Virol. 70 (2003) 91-98.

[6] D. Meyers, D. Posma, C. Panhuysen et al., Genomics. 23 (1994) 464-470.

[7] H. Neffen, C.D. Crisci, H. Busaniche, A. Yanez, Allergol, Immunopathol. (Madr.) 14 (1986) 413418.

[8] L.P. Tsarevsky, M.G. Romantsov, Successes of modern natural science 5 (2003) 95-97.

[9] I.V. Kozachenko, L.L. Akhmaltdinova, I.I. Godunova, Med. and Ecol. 4 (2006) 47-49.

[10] L.A. Masaylova, Hygienic approaches to assessing the level of public health risk from exposure to chemical environmental pollutants, Moscow, 2004. 